\title{
Analysing the Demographic and Socio-personal Characteristics of 'System of Wheat Intensification' (SWI) Adopter as well as Non-adopter Farmers: A Study in Samastipur District of Bihar State, India
}

\author{
Samrat Sikdar*, Satya Prakash and Shweta Kumari \\ Department of Extension Education, Dr. Rajendra Prasad Central Agricultural University, \\ Pusa, Samastipur, Bihar-848125, India \\ *Corresponding author
}

\section{A B S T R A C T}

\section{Keywords \\ SWI, Adopter, Non- adopter, \\ Demographic, Social}

Article Info

Accepted:

07 March 2020

Available Online:

10 April 2020
Wheat (Triticum aestivum L.) is world's most widely cultivated food grain crop. At initial decades of 21 st century, one probability of a great famine appeared in the world due to long drought in tropics and subtropics and at the same time it appeared more dangerously because of the climate change threat. System of Wheat Intensification (SWI) which is somewhat based on the fundamental principles of System of Rice Intensification (SRI) is a new wheat cultivation technique which might act as a significantly new weapon as a part of climate-smart farming. It is one of the promising technologies to increase productivity which ultimately contributes to the household level food security of rural marginal farmers. The present study was conducted in Samastipur district of Bihar state in India. 4 panchayats were selected from 2 blocks of Samastipur based on assumption that these blocks have the largest number of adopters of SWI technology. The total number of respondents (beneficiaries and non-beneficiaries) selected for the study was 60. Frequency, percentage, arithmetic mean, standard deviations were used as the statistical tools to analyse some demographic as well as socio-personal features of the adopters as well as non-adopters of SWI technique. Majority of the adopters $(50 \%)$ belong to young age group whereas majority of the non-adopters $(40 \%)$ belong to old age group. Level of education and annual family income of both the categories were studied also. Most of the adopter farmers $(70 \%)$ belong to small and marginal category on the basis of their land holdings but maximum non-adopters $(50 \%)$ belong to the medium category. Majority of the adopters $(50 \%)$ are the member of one social organisation, but majority of non-adopters $(56.67 \%)$ are not the member of any organization. Besides, it was found that adopters were using more cosmopolite sources of information (agricultural coordinator, block officials, scientists etc.) than the non-adopters. Even 50 percent adopters most often utilized T.V. as the mass media followed by newspapers and among non-adopters, only 30 percent respondents most often utilized T.V. as the mass media for information seeking.

\section{Introduction}

Wheat stands second in grain production in the world and most widely cultivated food crop. The Global area of wheat cultivation was $218.5 \mathrm{~m}$ ha compared to $156 \mathrm{~m}$ ha under rice. In India, wheat is second important staple food crop after rice. India has now be- 
come the second largest producer of wheat in the world with a production of $93.5 \mathrm{~m} \mathrm{t}$ (13.6 $\%$ of total world wheat production) from $29.7 \mathrm{~m}$ ha area with average productivity of $3.15 \mathrm{t} / \mathrm{ha}$. The major wheat producing states are Uttar Pradesh, Punjab, Haryana, Madhya Pradesh, Rajasthan, Bihar, Maharashtra, Gujarat, West Bengal and Uttarakhand. Introduction of semi dwarf varieties increased the consumption of fertilizer per unit area tremendously and promoted mechanization in agriculture. In one side it increased the overall production and postponed the near seen dangerous cloud of the great famine due to population explosion in the third world where there was very low growth rate of crop production as compared to population growth. However in long term advantages of green revolution were taken only by developed country and farmers who were fortified by irrigation, mechanization and high agro inputs. But at initial decades of 21 st century another probability of great famine appeared in the world due to long drought in tropical and subtropical and at the same time it appeared more dangerously because most of the developed countries adopted policies of using consumable grains into bio fuel production. Therefore, another very serious initiative was needed to increase the productivity of major crop in the very marginal land with low input and sustainable way. In this context, in many parts of the third world System of Wheat Intensification created government attention. Among winter crops, it contributes nearly about 49 per cent of food grains.

In Bihar, wheat is grown about 2.1 million hectare with a production and productivity of 4 million tonnes and 1.95 tonnes per hectare, respectively. Wheat has been the staple food of the majority of population of Bihar. It forms the very basis of foods security system of our state. Wheat production of our state has maintained an uprising trend despite of various unpredictable situations of weather uncertainties. In spite all of these achievements, the productivity picture of wheat in Bihar (24 q/ha) is not very encouraging, rather quite low when compared with national wheat productivity $(31.4 \mathrm{q} / \mathrm{ha})$. In Bihar rice-wheat culture is practiced in $80 \%$ of arable land area. A growing movement has emerged during the past few decades to question the role of the agricultural establishment in promotion practices that contribute to the social problems. Innovative agricultural practices not only address many environmental and social concerns, but also offer economically viable opportunities for growers, labourers, consumers, policy makers and many others in the entire food production system.

There is a need to intensify the cultivation of crops by using optimum input through BMP (Best Management Practices) for resource conservation. There is a need for adoption of intensive agricultural practices for increasing the productivity in wheat to ensure food security for the people. Wheat intensification is a new concept and goes with the system of rice intensification (SRI) principle. In case of SWI, all agronomic principles of SRI are put into practices and integrated with package of practices of wheat crop. The technology which has high potentiality to provide high wheat yield per drop of water and per $\mathrm{kg}$ of agricultural inputs (fertilizer, seed etc.) and application of other SRI principle to wheat crop, is known as system of wheat intensification (SWI). Adoption of this technology can increase the productivity of wheat by more than 2 times (Uphoff et al., 2012). The method is about managing the crop, soil and nutrients to promote a vibrant soil system that, in turn, pro-motes larger root systems. Therefore, System of wheat intensification (SWI) is an adoption of technique used in the system of rice intensification (SRI) methodology of 
increasing the productivity of crops by changing the management of plant, soil, water and nutrients while reducing external inputs use. Fortunately, experience with the system of rice intensification developed in Madagascar over 30 years ago by father Hendrei de Laulani'e offers some ways to make production system, cost effective, efficient and of increase climate secure.

The merit of system have now been demonstrated worldwide especially rice growing countries of Asia and many other countries as well as its concept and practices are now being extended beyond irrigated rice to wheat, ragi, sugarcane, beans and other crops (Thapa et al., 2011). System of wheat intensification has been tested as an innovative approach to increase productivity and being practiced in India, China, Ethiopia, Poland and USA. SRI has already been tested and evaluated by several NGOs, but System of wheat intensification is still a new technology for wheat cultivation in India. The main objective of this trail is to compare the yield from traditional practice with that from SWI (Khadka et al., 2011).

The prevalent system of wheat cultivation requires more chemical fertilizers and nearly $120-180 \mathrm{~kg}$ of seed per hectare. SWI use only 20-30 kg improved seed per hectare. 15-20 $\mathrm{cm}$ spacing between row to row and plant to plant, use of manure and organic seed treatment ensure higher yield. Sufficient spacing between the plants and sowing of two seed grains at one point facilitates desired moisture, aeration, nutrition and light to the crop roots. This helps faster growth of plants. Only 2-3 times irrigation and weeding through cono-weeder save times and expenses on labour. SWI is primarily based on these two principles of crop production first principle of root development and second principle of intensive care. System of wheat intensification (SWI) is one of the promising technologies to increase productivity which ultimately contributes to the household level food security of marginal farmers. It might act as a significant new technology towards the domain of climate-smart agriculture.

\section{Objective of the study}

The main objective of study is to analyse the level of ideas of SWI method and attitudes of the respondent farmers towards SWI in Samastipur district of Bihar state in India. The specific objective is to:

Exploring specific socio-economic and demographic features- age, education level, size of land holding, annual income of the family, social participation, source of information utilized and mass media exposure of adopters as well as non-adopters of SWI technology.

\section{Materials and Methods}

The study was conducted in Samastipur district of Bihar state. Samastipur district was selected purposively because the researcher's university/institute is located exactly here and thus it would be easily approachable. Moreover, the researcher is well acquainted with the culture, social customs and situations prevailed in this district. 2 specific blocks viz. Pusa and Morwa blocks have been selected for the study purpose based on assumption that the block has the largest number of adopters of SWI technology. 2 Panchayats viz. Thahara and Morsand were selected among 13 Panchayats of Pusa block and 2 Panchayats viz. Indarwara and Sarangpur were selected among 18 Panchayats of Morwa block.

A complete list of the adopters who have undergone through cultivation of wheat through SWI technology was obtained from District Agricultural Officer of Samastipur 
district in Bihar state. 15 adopters and 15 nonadopters respondents from each of 2 blocks were purposively selected. Therefore 30 beneficiary and 30 non-beneficiary respondents were selected. So, the total number of beneficiaries and non-beneficiaries selected for the study was 60 .

Only the primary data is used and that was collected through survey. Data has been collected through preparation of wellstructured interview schedule. On the basis of actual age of the respondent, they were categorized into three age groups i.e. Young age group (upto 35 years), Middle age group (36 to 50 years) and Old age group (above 50 years). For discerning the social participation status, Trivedi scale (1963, IARI) was used here. There were 4 distinct types of social participation status viz. No member of any organisation, Member of one organisation, Member of more than one organisation, office bearer of an organisation and for these 4 categories $0,1,2,3$ scores are given respectively. For analysing sources of information utilized, 8 sources were considered including both cosmopolite and localite sources; those are agricultural coordinator, block officials, scientists, relatives, neighbours, local leaders, demonstrations and farmers' fair.

The score of 4, 3, 2, 1 were given for the extent of use i.e. most often, often, sometimes and never respectively. For exploring the mass media utilization by the adopter as well non-adopter respondents, 4 mass media were considered i.e. radio, T.V., newspaper, farm magazine. The respondents were asked to respond their degree of participation or usage of mass media in terms of most often, often, sometimes and never and the score 4, 3, 2, 1 were given respectively. Frequency and percentage were used as the statistical tools in each case to explore these 4 sociodemographic parameters (Table 1).

\section{Results and Discussion}

\section{Age}

Age of the respondents is a variable which forms the centre of study in social science researches. Hardly, there is a study where this factor is ignored because it has a definite bearing on the study as a whole. Age constitutes an important variable which influences adoption behaviour of an individual regarding new agricultural technology. On the basis of their age, the adopters and non-adopters were classified into three age groups viz. young (less than 35 years), middle age group (35 years to 50 years) and old age group (above 50 years).

The table 2 shows that majority $(50 \%)$ of the adopters were belonging to young age group followed by middle age group (30\%) and old age group (20\%). Similarly, majority of the non-adopters (40\%) were of old age group followed by middle age group $(33.33 \%)$ and young age group (26.67\%). That precisely indicates that the young age and middle aged respondents were more exposed to modern technology dissemination of SWI method of wheat crop as they were more receptive of new ideas with less bondage for traditional as found in old age group.

\section{Education level}

Education is an important indicator of socioeconomic status that determines the rate of adoption of any technology. It has been observed that higher is the level of education, greater is the adoption rate of technology. It is easier to convince educated adopters about usefulness of any technology than that to any illiterate adopters.

The adopters and non-adopters were classified into four categories on the basis of their educational attainment.

Table 3 reveals that majority of adopters have 
education up to intermediate i.e. 30 per cent, followed by up to high school (23.34\%), up to middle school (16.67\%), graduation and above $(13.33 \%)$, can read and write $(10 \%)$ and minimum percentage of adopters are illiterate $(6.66 \%)$. But in case of non-adopters majority of the respondents have education up to high school (30\%), followed by up to middle school (20\%), can read and write $(16.67 \%)$, up to intermediate $(13.33 \%)$ and $10 \%$ of non-adopters have education graduation and above and $10 \%$ non-adopters were illiterate.

\section{Size of land holding}

Land is an important income generating asset in rural areas. It serves as base for successful implementation of any agricultural technology because it provides cushion to adopters in taking risk in participating new programmes. The respondents were grouped according to size of land possessed by them. The respondents were divided into three categories on the basis of their size of holding i.e. marginal, small and large farmers.

Table 4 shows that among the adopters, majority of them belonged to small farmers i.e. $40 \%$ followed by marginal farmers $(30 \%)$, medium farmers $(20 \%)$ and large farmers $(10 \%)$. So, it is evident that more than twothird of beneficiaries were small and marginal farmers. Among the non-adopters, 50\% were medium farmers, followed by marginal farmer $(20 \%)$, small farmer $(16.66 \%)$ and large farmers $(13.33 \%)$.

\section{Annual family income}

The income of the respondents seems to have significant influence on their socio-economic status and it plays a key role in adoption of any new technology. Annual family income was measured using a measuring scale by grouping income categories as it was difficult to get exact income details from respondents so income was grouped in a range and respondents were categorized into four groups as very low, low, medium and high income group.

Table 5 depicts that majority of adopters were from medium income group (40\%) followed by low income group (30\%). The respondents fell in category of high income i.e. $16.66 \%$ and least number of respondents was from very low income group which was only $13.34 \%$. But in case of non-adopters, majority of respondents were from very low income group which is 50 per cent, low 30 per cent and medium 20 per cent respectively. In case of non-adopters, none of the respondent fell in high income group.

\section{Social participation}

Social participation is an important variable in the study of social sciences. Social participation refers to the extent of involvement of adopters and non-adopters in the various social institutions such as cooperatives, panchayats, bank, youth clubs, NGO, mahila mandal and others. On the basis of extent of involvement and the position they hold in different organization, the adopters and non-adopters have been categorized into 4 categories.

Table 6 shows that majority of the adopters were member of one organization i.e. $50 \%$ followed by not member of any organization i.e. $30 \%$ while office bearer and member of more than one organization were only $10 \%$. In case of non-adopters, $56.67 \%$ were not member of any organization followed by $33.33 \%$ respondents were member of one organization and $6.66 \%$ of non-adopters were member of more than one organization and $3.33 \%$ of the respondents fell in the category of office bearer. 
Table.1 Selection of the respondents

\begin{tabular}{|c|c|c|c|c|c|}
\hline Sl. No. & $\begin{array}{c}\text { Name of the } \\
\text { block }\end{array}$ & $\begin{array}{c}\text { Name of the } \\
\text { selected villages }\end{array}$ & $\begin{array}{l}\text { Total number of } \\
\text { the respondents }\end{array}$ & $\begin{array}{l}\text { Selected } \\
\text { adopters }\end{array}$ & $\begin{array}{l}\text { Selected non- } \\
\text { adopters }\end{array}$ \\
\hline 1. & Pusa & $\begin{array}{l}\text { Thahara } \\
\text { Morsand }\end{array}$ & $\begin{array}{l}15 \\
15\end{array}$ & $\begin{array}{l}8 \\
7\end{array}$ & $\begin{array}{l}7 \\
8\end{array}$ \\
\hline 2. & Morwa & $\begin{array}{l}\text { Indrawara } \\
\text { Sarangpur }\end{array}$ & $\begin{array}{l}15 \\
15\end{array}$ & $\begin{array}{l}7 \\
8\end{array}$ & $\begin{array}{l}8 \\
7\end{array}$ \\
\hline
\end{tabular}

Table.2 Frequency and percentage distribution of adopters and non-adopters with respect to their age

\begin{tabular}{|c|c|c|c|c|c|}
\hline S. No. & Age group & \multicolumn{2}{|c|}{ Adopters (n=30) } & \multicolumn{2}{|c|}{ Non-adopters (n=30) } \\
\cline { 2 - 6 } & Frequency & Percentage & Frequency & Percentage \\
\hline $\mathbf{1 .}$ & $\begin{array}{c}\text { Young age group } \\
\text { (up to 35 years) }\end{array}$ & 15 & 50 & 8 & 26.67 \\
\hline $\mathbf{2 .}$ & $\begin{array}{c}\text { Middle age group } \\
\text { (36-50 years) }\end{array}$ & 9 & 30 & 10 & 33.33 \\
\hline $\mathbf{3 .}$ & $\begin{array}{c}\text { Old age group } \\
\text { (Above 50 years) }\end{array}$ & 6 & 20 & 12 & 40 \\
\hline & Total & 30 & 100 & 30 & 100 \\
\hline
\end{tabular}

Table.3 Frequency and percentage distribution of adopters and non-adopters with respect to their education level

\begin{tabular}{|l|l|l|l|l|l|}
\hline $\begin{array}{c}\text { Sl. } \\
\text { No. }\end{array}$ & \multicolumn{1}{|c|}{ Categories } & \multicolumn{2}{|c|}{ Adopters $(\mathbf{n = 3 0})$} & \multicolumn{2}{c|}{ Non-adopters $(\mathbf{n}=30)$} \\
\hline 1. & Illiterate & 02 & 6.66 & 03 & 10 \\
\hline 2. & Can read and write & 03 & 10 & 05 & 16.67 \\
\hline 3. & Up to middle school & 05 & 16.67 & 06 & 20 \\
\hline 4. & Up to high school & 07 & 23.34 & 09 & 30 \\
\hline 5. & Up to intermediate school & 09 & 30 & 04 & 13.33 \\
\hline 6. & Graduation and above & 04 & 13.33 & 03 & 10 \\
\hline & Total & 30 & 100 & 30 & 100 \\
\hline
\end{tabular}

Table.4 Frequency and percentage distribution of adopters and non-adopters with respect to their size of land holding

\begin{tabular}{|l|l|l|l|l|l|}
\hline Sl. No. & \multicolumn{1}{|c|}{ Categories } & \multicolumn{2}{c|}{ Adopters $(\mathbf{n}=\mathbf{3 0})$} & \multicolumn{2}{c|}{ Non-adopters $(\mathbf{n}=\mathbf{3 0})$} \\
\cline { 3 - 6 } & & Frequency & Percentage & Frequency & Percentage \\
\hline 1. & Marginal $($ up to 2.5 acre) & 9 & 30 & 6 & 20 \\
\hline 2. & Small $(>2.5$ to 5 acre) & 12 & 40 & 5 & 16.66 \\
\hline 3. & Medium $(>5$ to 10 acre $)$ & 6 & 20 & 15 & 50 \\
\hline 4. & Large $(>10$ acre $)$ & 3 & 10 & 4 & 13.33 \\
\hline & Total & 30 & 100 & 30 & 100 \\
\hline
\end{tabular}


Table.5 Frequency and percentage distribution of adopters and non-adopters with respect to their family annual income

\begin{tabular}{|l|l|l|l|l|l|}
\hline \multirow{2}{*}{$\begin{array}{c}\text { Sl. } \\
\text { No. }\end{array}$} & \multicolumn{1}{|c|}{ Categories } & \multicolumn{2}{c|}{ Adopters $(\mathbf{n = 3 0})$} & \multicolumn{2}{c|}{ Non-adopters $(\mathbf{n = 3 0})$} \\
\hline 1. & Very low (up to 1 lakh) & Frequency & Percentage & Frequency & Percentage \\
\hline 2. & Low $(1-1.5$ lakh $)$ & 9 & 13.34 & 15 & 50 \\
\hline 3. & Medium $(1.5-2$ lakh $)$ & 12 & 30 & 9 & 30 \\
\hline 4. & High $(2$ lakh and above $)$ & 5 & 40 & 6 & 20 \\
\hline & Total & 30 & 16.66 & 0 & 00 \\
\hline
\end{tabular}

Table.6 Frequency and percentage distribution of adopters and non-adopters with respect to their social participation

\begin{tabular}{|l|l|l|l|l|l|}
\hline \multirow{2}{*}{$\begin{array}{c}\text { SI. } \\
\text { No. }\end{array}$} & \multicolumn{1}{|c|}{ Category } & \multicolumn{2}{c|}{ Adopters $(\mathbf{n = 3 0})$} & \multicolumn{2}{c|}{ Non-adopters $(\mathbf{n = 3 0})$} \\
\hline 1. & Not member of any organization & 9 & 30 & 17 & 56.67 \\
\hline 2. & Member of one organization & 15 & 50 & 10 & 33.34 \\
\hline 3. & $\begin{array}{l}\text { Member of more than one } \\
\text { organization }\end{array}$ & 3 & 10 & 2 & 6.66 \\
\hline 4. & $\begin{array}{l}\text { Office bearer of an organization } \\
\text { Total }\end{array}$ & 3 & 10 & 1 & 3.33 \\
\hline & Total & 30 & 100 & 30 & 100 \\
\hline
\end{tabular}

Table.7 Frequency and percentage distribution of adopters and non-adopters with respect to their source of information utilized

\begin{tabular}{|c|c|c|c|c|c|c|c|c|c|}
\hline \multirow{3}{*}{$\begin{array}{l}\text { SI. } \\
\text { No. }\end{array}$} & \multirow[t]{3}{*}{ Categories } & \multicolumn{4}{|c|}{ Adopters $(n=30)$} & \multicolumn{4}{|c|}{ Non-Adopters $(\mathbf{n}=\mathbf{3 0})$} \\
\hline & & Most often & Often & $\begin{array}{c}\text { Sometime } \\
\mathrm{s}\end{array}$ & Never & $\begin{array}{l}\text { Most } \\
\text { often }\end{array}$ & Often & $\begin{array}{c}\text { Sometime } \\
\mathrm{s}\end{array}$ & Never \\
\hline & & Freq. $(\%)$ & Freq. $(\%)$ & Freq. $(\%)$ & Freq. $(\%)$ & Freq. $(\%)$ & Freq. $(\%)$ & Freq. $(\%)$ & Freq. $(\%)$ \\
\hline 1. & $\begin{array}{l}\text { Agricultural } \\
\text { coordinator }\end{array}$ & $\begin{array}{c}15 \\
(50)\end{array}$ & $\begin{array}{c}7 \\
(23.34)\end{array}$ & $\begin{array}{c}5 \\
(16.66)\end{array}$ & $\begin{array}{c}3 \\
(10)\end{array}$ & $\begin{array}{c}12 \\
(40)\end{array}$ & $\begin{array}{c}9 \\
(30)\end{array}$ & $\begin{array}{c}6 \\
(20)\end{array}$ & $\begin{array}{c}3 \\
(10)\end{array}$ \\
\hline 2. & Block official & $\begin{array}{c}9 \\
(30) \\
\end{array}$ & $\begin{array}{c}6 \\
(20) \\
\end{array}$ & $\begin{array}{c}8 \\
(26.66)\end{array}$ & $\begin{array}{c}7 \\
(23.34)\end{array}$ & $\begin{array}{c}5 \\
(16.66)\end{array}$ & $\begin{array}{c}6 \\
(20)\end{array}$ & $\begin{array}{c}9 \\
(30)\end{array}$ & $\begin{array}{c}10 \\
(33.34)\end{array}$ \\
\hline 3. & Scientists & $12(40)$ & $\begin{array}{c}9 \\
(30)\end{array}$ & $\begin{array}{c}6 \\
(20)\end{array}$ & $\begin{array}{c}3 \\
(10)\end{array}$ & $\begin{array}{c}6 \\
(20)\end{array}$ & $\begin{array}{c}8 \\
(26.66)\end{array}$ & $\begin{array}{c}7 \\
(23.34)\end{array}$ & $\begin{array}{c}9 \\
(30)\end{array}$ \\
\hline 4. & Relatives & $\begin{array}{c}18 \\
(60)\end{array}$ & $\begin{array}{c}6 \\
(20)\end{array}$ & $\begin{array}{c}4 \\
(13.33)\end{array}$ & $\begin{array}{c}2 \\
(6.67)\end{array}$ & $\begin{array}{c}4 \\
(13.33)\end{array}$ & $\begin{array}{c}12 \\
(40)\end{array}$ & $\begin{array}{c}6 \\
(20)\end{array}$ & $\begin{array}{c}8 \\
(26.67)\end{array}$ \\
\hline 5. & Neighbour & $\begin{array}{c}16 \\
(53.33)\end{array}$ & $\begin{array}{c}8 \\
(26.67)\end{array}$ & $\begin{array}{c}3 \\
(10)\end{array}$ & $\begin{array}{c}3 \\
(10)\end{array}$ & $\begin{array}{c}9 \\
(30)\end{array}$ & $\begin{array}{c}11 \\
(36.66)\end{array}$ & $\begin{array}{c}6 \\
(20)\end{array}$ & $\begin{array}{c}4 \\
(13.34)\end{array}$ \\
\hline 6. & Local leaders & $\begin{array}{c}15 \\
(50)\end{array}$ & $\begin{array}{c}5 \\
(16.66)\end{array}$ & $\begin{array}{c}7 \\
(23.34)\end{array}$ & $\begin{array}{c}3 \\
(10)\end{array}$ & $\begin{array}{c}3 \\
(10)\end{array}$ & $\begin{array}{c}7 \\
(23.34)\end{array}$ & $\begin{array}{c}9 \\
(30)\end{array}$ & $\begin{array}{c}11 \\
(36.66)\end{array}$ \\
\hline 7. & Demonstration & $\begin{array}{c}12 \\
(40)\end{array}$ & $\begin{array}{c}9 \\
(30)\end{array}$ & $\begin{array}{c}6 \\
(20)\end{array}$ & $\begin{array}{c}3 \\
(10)\end{array}$ & $\begin{array}{c}6 \\
(20)\end{array}$ & $\begin{array}{c}8 \\
(26.67)\end{array}$ & $\begin{array}{c}7 \\
(23.33)\end{array}$ & $\begin{array}{c}9 \\
(30)\end{array}$ \\
\hline 8. & Farmers fair & $\begin{array}{c}15 \\
(50)\end{array}$ & $\begin{array}{c}7 \\
(23.34)\end{array}$ & $\begin{array}{c}6 \\
(20)\end{array}$ & $\begin{array}{c}2 \\
(6.66)\end{array}$ & $\begin{array}{c}6 \\
(20)\end{array}$ & $\begin{array}{c}9 \\
(30)\end{array}$ & $\begin{array}{c}5 \\
(16.66)\end{array}$ & $\begin{array}{c}10 \\
(33.34)\end{array}$ \\
\hline
\end{tabular}


Table.8 Frequency and percentage distribution of adopters and non-adopters according to mass media utilization

\begin{tabular}{|c|c|c|c|c|c|c|c|c|c|}
\hline \multirow{3}{*}{$\begin{array}{l}\text { Sl. } \\
\text { No. }\end{array}$} & \multirow[t]{3}{*}{ Categories } & \multicolumn{4}{|c|}{ Adopters $(\mathrm{n}=30)$} & \multicolumn{4}{|c|}{ Non-Adopters $(n=30)$} \\
\hline & & $\begin{array}{l}\text { Most } \\
\text { often }\end{array}$ & Often & Sometimes & Never & $\begin{array}{l}\text { Most } \\
\text { often }\end{array}$ & Often & $\begin{array}{c}\text { Sometime } \\
\text { S }\end{array}$ & Never \\
\hline & & Freq. $(\%)$ & Freq. $(\%)$ & Freq. $(\%)$ & Freq. $(\%)$ & Freq. $(\%)$ & Freq.(\%) & Freq. $(\%)$ & Freq. $(\%)$ \\
\hline 1. & Radio & $\begin{array}{c}12 \\
(40)\end{array}$ & $\begin{array}{c}9 \\
(30)\end{array}$ & $\begin{array}{c}6 \\
(20)\end{array}$ & $\begin{array}{c}3 \\
(10)\end{array}$ & $\begin{array}{c}6 \\
(20)\end{array}$ & $\begin{array}{c}7 \\
(23.34)\end{array}$ & $\begin{array}{c}9 \\
(30)\end{array}$ & $\begin{array}{c}8 \\
(26.66)\end{array}$ \\
\hline 2. & T.V. & $\begin{array}{c}15 \\
(50)\end{array}$ & $\begin{array}{c}6 \\
(20)\end{array}$ & $\begin{array}{c}7 \\
(23.34)\end{array}$ & $\begin{array}{c}2 \\
(6.66)\end{array}$ & $\begin{array}{c}9 \\
(30)\end{array}$ & $\begin{array}{c}5 \\
(16.66)\end{array}$ & $\begin{array}{c}12 \\
(40)\end{array}$ & $\begin{array}{c}4 \\
(13.34)\end{array}$ \\
\hline 3. & Newspaper & $\begin{array}{c}13 \\
(43.34)\end{array}$ & $\begin{array}{c}8 \\
(26.66)\end{array}$ & $\begin{array}{c}6 \\
(20)\end{array}$ & $\begin{array}{c}3 \\
(10)\end{array}$ & $\begin{array}{c}3 \\
(10)\end{array}$ & $\begin{array}{c}6 \\
(20)\end{array}$ & $\begin{array}{c}13 \\
(43.34)\end{array}$ & $\begin{array}{c}8 \\
(26.66)\end{array}$ \\
\hline 4. & $\begin{array}{l}\text { Farm } \\
\text { magazine }\end{array}$ & $\begin{array}{c}7 \\
(23.34)\end{array}$ & $\begin{array}{c}8 \\
(26.66)\end{array}$ & $\begin{array}{c}11 \\
(36.66)\end{array}$ & $\begin{array}{c}4 \\
(13.33)\end{array}$ & $\begin{array}{c}4 \\
(13.33)\end{array}$ & $\begin{array}{c}6 \\
(20)\end{array}$ & $\begin{array}{c}12 \\
(40)\end{array}$ & $\begin{array}{c}8 \\
(26.66)\end{array}$ \\
\hline
\end{tabular}

\section{Sources of information utilized}

Source of information utilized is one of the most important variables that play an important role in adoption of new technology. Source of information here refers out-side contact farmers had for acquiring themselves with the latest technologies. As the adopters established close linkage with various information sources viz. agriculture coordinator, block official, scientists, Relative, Neighbour, Local leaders, Demonstration, Farmers fair, they possess significant level of adoption.

Local leaders at the panchayat level, neighbour and relatives were the 'most often', 'often' and 'sometimes' used sources of information by majority of adopters (20$60 \%$ ). Among non-adopters majority was 'often' and 'sometimes' used source of information (20-50\%). Their frequency of use was very occasional or rare.

Among adopters, majority of them were using these source of information 'often' and 'most often' such as scientist and farmers fair and rest other sources of information such as agricultural coordinator, block officials, demonstration were used 'often' and 'sometimes' (20-50\%). About $10-25 \%$ of adopters were found to have never consulted any of these cosmopolite interpersonal sources of information. Among non-adopters, $20-30 \%$ were found to be 'often' and 'sometimes' consulting these cosmopolite sources of information, while another 10-30\% of them 'never' approaching these cosmopolite interpersonal source of information. Thus, it can be concluded that adopters were using more of these cosmopolite sources than the non-adopters.

\section{Mass media utilization}

Mass media like radio, television, newspaper and farm magazine provide relevant and timely information to farmers. Frequency of use of such mass media by farmers was studied using a simple schedule prepared for study.

Table 8 suggests that $50 \%$ adopters were 'most often' utilized T.V. followed by $30 \%$ adopters 'often utilized' Radio, 36.66\% adopters 'sometimes' utilized Farm magazine and $13.34 \%$ adopters 'never' utilized Farm magazine. Whereas in case of non-adopters, $30 \%$ respondents were 'most often' utilized T.V., 23.34\% respondents 'often utilized' 
Radio, $43.34 \%$ respondent utilized Newspaper 'sometimes' but 26.66\% respondents 'never' utilized Radio, Newspaper, and Farm magazine.

The social science research leading to degree has its own limitation in terms of time and resources. This study also fall in the category of social sciences faced a lot of constraints in generalizing the findings beyond the purview of the research areas. However, what emerged out of this study that its findings may be taken as appoint of reference to start of drive for improving the extent of adoption especially in those component where a lot a ground still seems to be covered.

SWI is a fresh technical intervention of increasing the productivity of crops by changing the management of plant, soil, water and nutrients while reducing external inputs. It is one of the promising technologies to increase productivity of wheat which ultimately contributes to the household level food security of marginal farmers as well as the common mass. The sharpness and productivity of finding depends on selective use of variables responsible for affecting the level of knowledge of farmers about SWI as well as their attitude towards SWI. The variables which were found accountable for these should be profitable manipulated. Some of the variables which were found within manageable range of the farmers and some are to be induced by change promoters. There were several constraints in adopting SWI technology but adopters were able to remove these constraints successfully as they learned various technical knowhow during the training programme, whereas non-adopters felt more constraint as they lack that particular knowhow. Major constraint for partial and non-adopters were non availability of labourers. The sharpness and productivity of finding depends on selective use of variables responsible for affecting the extent of adoption. The variables which were found accountable for adoption of System of Wheat Intensification (SWI) should be profitable manipulated. Some of the variables which were found within manageable range of the farmers and some are to be induced by change promoters. There should be concerted drive to induce sense of unique venture in farmers through motivational drives.

\section{References}

Anonymous 2009. system of rice intensification annual Report 20082009, AICRP on water Management, WTCER, Bhubnesnwar pp 24.

Doberman A. (2004) A critical assessment of the system or rice intensification (SRI) Agricultural systems 79, 261-281.

Khadka, R.B. and Raut, P. (2011) System of Wheat Intensification (SWI): A new concept on low input technology for increasing wheat yield in marginal land. Mercy Crops Nepal

Kumari, Maya. Srivastava, A.K.and Sinha, Nidhi. (2010). Extent of knowledge of farm women on nutrition. Indian research journal of Extension Education, 10 (1). 65-68.

Kumar, D. (2002). Attitude of farm women towards dairy cooperative in Bihar. A study in Samastipur district. M.Sc. Thesis R.A.U., Pusa, Samastipur.

Kuwar. (2002). Adoption of mushroom cultivation by rural women of Kanpur, Uttar Pradesh: Problems and Perspectives. Progressive Agriculture. 2 (1): 31-33.

Laguna R.J.P. (2002) system of Rice intensification with less input Indian Journal of Agricultural Economics 60 (3): 458-472.

Relker, P. M.; DGM (Tech.), TDS and HO. (2011). System of wheat intensification (SWI). Technical Digest, issue 13, Jan. 2011. 
Thapa, T., Chaudhary, P. And Ghimire, S. agricultural practices. Report (2011). Increasing Household Food Security through System of Wheat Intensification(SWI) Techniques. accompanying presentation on 'System of Rice Intensification(SRI) Mercy Crops Nepal.

Uphoff, N. (2012). Raising small holder food and beyond: Coping with Climate change'. World Bank, Washington, crop yields with climate-smart DC.

\section{How to cite this article:}

Samrat Sikdar, Satya Prakash and Shweta Kumari. 2020. Analysing the Demographic and Socio-personal Characteristics of 'System of Wheat Intensification' (SWI) Adopter as well as Non-adopter Farmers: A Study in Samastipur District of Bihar State, India. Int.J.Curr.Microbiol.App.Sci. 9(04): 476-485. doi: https://doi.org/10.20546/ijcmas.2020.904.056 